\title{
Discovery of the West Caribbean Ocellated Geckolet, Sphaerodactylus argus (Squamata: Sphaerodactylidae), on Old Providence Island in the Colombian
}

\section{Caribbean}

\author{
Diego A. Gómez-Sánchez
}

Reserva Natural Rey Zamuro-Matarredonda, San Martín de los Llanos, Meta, Colombia, diegophidio@gmail.com

Edited by: Robert Powell. Date of publication: 1 June 2021.

Citation: Gómez-Sánchez, DA (2021) Discovery of the West Caribbean Ocellated Geckolet, Sphaerodactylus argus (Squamata: Sphaerodactylidae) on Old Providence Island in the Colombian Caribbean. Caribbean Herpetology, 75, 1-3.

DOI: https://doi.org/10.31611/ch.75

The West Caribbean Ocellated Geckolet, Sphaerodactylus argus Gosse, is a small, diurnally active gecko with a wide distribution in the Western Caribbean. It occurs on Jamaica, Cuba, the Bahamas (introduced on Bimini and New Providence islands), the Corn Islands of Nicaragua, Key West and Stock Island of Florida (USA), and in the Bocas del Toro region of Panama and the Yucatan Peninsula of Mexico (Harris \& Kluge 1984; Schwartz \& Henderson 1991; Uetz et al. 2020). Thomas (1975) noted the difficulty in distinguishing native from introduced populations of the species. In Colombia, this species is known only from San Andres Island (Dunn \& Saxe 1950; Tamsitt \& Valdivieso 1963; Valdivieso \& Tamsitt 1963; Ayala 1986; McNish 2011; Caicedo-Portilla 2014). The elevational range of S. argus is $0-600 \mathrm{~m}$ (Thomas 1975).

During the revision of the reptile collection at the Natural History Museum C. J. Marinkelle (ANDES-R), I found two specimens of S. argus from Old Providence Island (ANDES-R-614: 13.333716, -81.375659; 30 m; ANDES-R-1403: 13.340274, -81.369961; 103 m; Figs. 1B \& 1D), Insular Department, Colombia. These records expand the known range of this lizard about 90 straight-line $\mathrm{km}$ northeast of the nearest previously documented locality on San Andres Island in the same Colombian department (Fig. 1A). Additionally, I discovered two specimens of $S$. argus from San Andres Island (ANDES-R-610-611: 12.536490, -81.711532; 29 m; Figs. 1A \& 1C) that represent the southernmost known locality for the species on this island.

These specimens provide the first evidence of $S$. argus on Old Providence Island and represent the northernmost localities of the species in Colombian territory. Previous visits by herpetologists to the Archipelago of San Andres, Old Providence, and Santa Catalina failed to record any species of Sphaerodactylus from Old Providence Island. Therefore, the colonization of Old Providence by S. argus probably occurred in recent years. Some individuals might have arrived on the island by rafting on flotsam from another Caribbean island where this species occurs but were more likely dispersed by incidental human activity (Hoogmoed \& Avila-Pires 2015), with the latter scenario a possible consequence of frequent movement of people and goods between San Andres and Old Providence islands (McNish 2011; Dunn \& Saxe 1950). This species is listed as being of Least Concern (LC) on the IUCN Red List of Threatened Species (Caicedo et al. 2017) but its conservation status in Colombia has not been assessed. Demographic studies are needed to evaluate the current population trends of the species on both Colombian islands.

\section{Acknowledgments}

I thank Alejandro Corrales-García for support while working with the reptile collection at the MNH-C.J. Marinkelle (ANDES-R), confirming the identity of the specimens, and help making the map. I also thank Juan P. Ramirez for his valuable comments on the manuscript. 

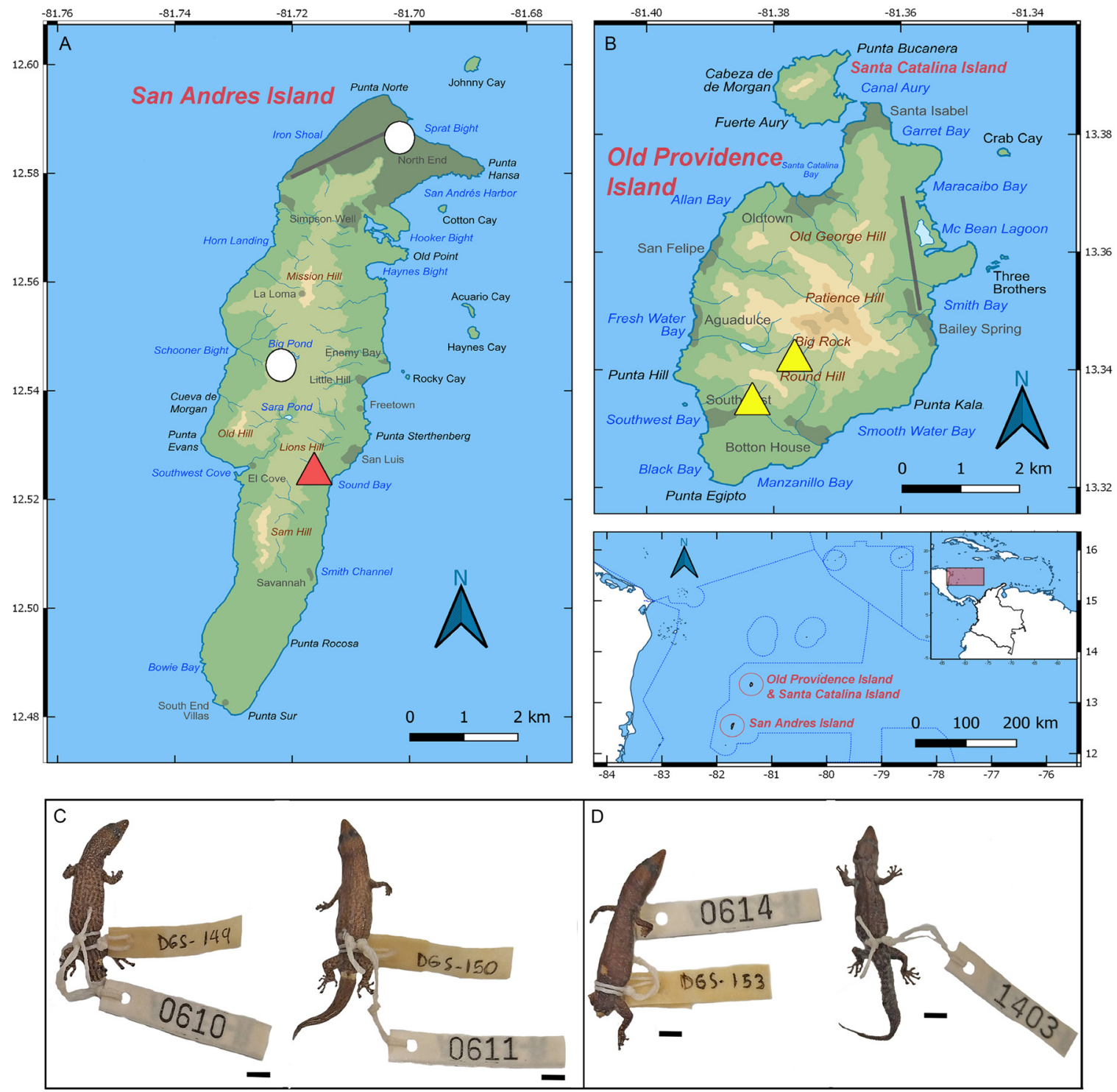

Figure 1. Distribution of Sphaerodactylus argus in the Colombian Caribbean. (A) San Andres island; circles mark previously known records (see references in text) and the red triangle indicates the new southernmost record on the island. (B) Old Providence Island; yellow triangles mark the first records from the island. (C) New specimens from San Andres (ANDES-R-610-611). (D) First specimens from Old Providence (ANDES-R-614, 1403). Scale bar in photos, $5 \mathrm{~mm}$. Photos courtesy of Alejandro Corrales-García.

\section{References}

Ayala SC (1986) Saurios de Colombia: lista actualizada, y distribución de ejemplares colombianos en los museos. Caldasia, 6, 71-75.

Caicedo-Portilla JR (2014) Redescubrimiento de Mabuya berengerae, Mabuya pergravis (Squamata: Scincidae) y Coniophanes andresensis (Squamata: Colubridae) y evaluación de su estado de amenaza en las islas de San Andrés y Providencia, Colombia. Caldasia, 36, 181-121.

Caicedo JR, Lee J, Mandujano RC, Wilson BS, Hedges SB, Fong A (2017) Sphaerodactylus argus. The IUCN Red List of Threatened Species, 2017, e.T198439A2526550. Available at https://www.iucnredlist.org/species/198439/2526550. Accessed 24 March 2021. 
Dunn ER, Saxe LH (1950) Results of the Catherwood-Chaplin West Indies Expedition, 1948. Part. 5. Amphibians and reptiles of San Andrés and Providencia. Proceedings of the Academy of Natural Sciences of Philadelphia, 102, 141-165.

Harris DM, Kluge AG (1984) The Sphaerodactylus (Sauria: Gekkonidae) of Middle America. Occasional Papers of the Museum of Zoology University of Michigan, 706, 1-59.

Hoogmoed SM, Avila-Pires TCS (2015) Lepidodactylus lugubris (Duméril \& Bibron 1836) (Reptilia: Gekkonidae), an introduced lizard new for Brazil, with remarks on and correction of its distribution in the New World. Zootaxa, 4000, 90-110.

McNish, T (2011) La Fauna del Archipiélago de San Andrés, Providencia y Santa Catalina, Colombia, Sudamérica (Colomba Andina de Impresos S.A., Bogotá D.C., Colombia).

Schwartz A, Henderson RW (1991) Amphibians and Reptiles of the West Indies. Descriptions, Distributions, and Natural History (University of Florida Press, Gainesville).

Tamsitt JR, Valdivieso D (1963) The herpetofauna of the Caribbean islands San Andrés and Providencia. Revista de Biología Tropical, 11, 131-139.

Thomas, R (1975) The argus group of West Indian Sphaerodactylus (Sauria: Gekkonidae). Herpetologica, 31, 177-195.

Uetz P, Freed P, Hošek J (eds) (2020) The Reptile Database. Available at http://www.reptiledatabase.org/. Accessed 24 March 2021.

Valdivieso D, Tamsitt JR (1963) A checklist and key to the amphibians and reptiles of Providencia and San Andres. Caribbean Journal of Science, 3, 77-79. 